\title{
Analysis of the candidate 8p2 I tumour suppressor, BNIP3L, in breast and ovarian cancer
}

\author{
J Lai', J Flanagan', WA Phillips², G Chenevix-Trench ${ }^{1,3}$ and J Arnold*,' \\ 'The Queensland Institute of Medical Research, PO Box Royal Brisbane Hospital, Herston, Queensland 4006, Australia; ${ }^{2}$ Peter MacCallum Cancer \\ Institute, St Andrews' Place, East Melbourne, Victoria 3002, Australia; ${ }^{3}$ Department of Pathology, University of Queensland, St Lucia, Brisbane, \\ Queensland 6067, Australia
}

Loss of heterozygosity $(\mathrm{LOH})$ on the short arm of chromosome 8, at 8p I 2-p23, is one of the most frequent genetic events in both breast and ovarian cancer, suggesting the location of a shared tumour suppressor gene. Microcell-mediated chromosome transfer of chromosome 8 suppresses tumorigenicity and growth of colorectal and prostate cancer cell lines, further supporting the presence of a tumour suppressor gene on $8 \mathrm{p}$. We have taken a candidate gene approach to try to identify this tumour suppressor gene at $8 \mathrm{p} / 2-$ p23. BNIP3L, which has sequence homology to pro-apoptotic proteins and the ability to suppress colony formation in soft agar, is located at 8p2I, within a region of ovarian cancer $\mathrm{LOH}$, breast cancer $\mathrm{LOH}$ and prostate cancer metastasis suppression. BNIP3L expression was assessed by both RT-PCR and Northern blot analysis in breast and ovarian cancer cell lines and found to be expressed at similar levels relative to expression in their respective normal epithelial cell lines. Genetic analysis of BNIP3L in 40 primary ovarian and 25 primary breast tumours identified one somatic, intronic mutation in one ovarian tumour, as well as several polymorphisms, including one resulting in an amino-acid substitution. These data suggest that BNIP3L is unlikely to be the target of $8 p$ $\mathrm{LOH}$ in ovarian or breast cancer.

British Journal of Cancer (2003) 88, 270 -276. doi:I0.1038/sj.bjc.6600674 www.bjcancer.com

(c) 2003 Cancer Research UK

Keywords: BNIP3L; DHPLC; 8p2I; LOH; cancer

Breast and ovarian cancers are the leading and fifth leading causes of cancer deaths, respectively, in women in developed countries. Both cancers are epithelial in origin and share some common genetic and epidemiological risk factors (Claus et al, 1996). While some of the genes involved in predisposition to familial breast and ovarian cancer are known (Claus et al, 1996; Welsch and King, 2001), little is understood about the somatic molecular changes that occur during the development of sporadic breast and ovarian cancer. Few genes have been found to be frequently downregulated in these tumours, and even fewer to carry frequent mutations (Liu and Ganesan, 2002).

The highest rates of loss of heterozygosity $(\mathrm{LOH})$ in breast cancer are found at $17 \mathrm{p}, 8 \mathrm{p}$ and $7 \mathrm{q}$, while in ovarian cancer they are at 17p, 17q, 8p, 22q and 18q (Callahan et al, 1992; Shelling et al, 1995; Phelan et al, 1998; Seitz et al, 2000; Pribill et al, 2001). LOH has been reported at $8 \mathrm{p} 12-8 \mathrm{p} 23$ in over $50 \%$ of primary breast tumours (Wang et al, 1999; Yokota et al, 1999). Similarly, LOH occurs in over $50 \%$ of ovarian tumors at p12-p23 (Brown et al, 1999; Wright et al, 1998). The occurrence of this common region of $\mathrm{LOH}$ in breast and ovarian cancer suggests that $8 \mathrm{p} 12-23$ probably harbours one or more tumour suppressor genes that are somatically inactivated in these neoplasms.

The BNIP3L gene is located between markers D8S1752 and D8S1989 that map to 8p21 in the smallest region of overlap (SRO) identified by LOH analysis of breast and ovarian tumours (Seitz et al, 2000; Brown et al, 1999), and to a region of prostate cancer metastasis suppression (Nihei et al., 1996). BNIP3L encodes a

*Correspondence: Dr J Arnold; Email: jeremyA@qimr.edu.au

Received 24 June 2002; revised 26 September 2002; accepted 30 September 2002 protein that is homologous to the proapoptotic protein BNIP3 (Matsushima et al, 1998; Chen et al, 1999; Imazu et al, 1999; Yasuda et al, 1999). Several well-characterised tumour suppressor genes such as PTEN, p53 and $R B$ have been shown to function through the control of apoptosis (Bellamy, 1997; Zornig et al, 2001), making $B N I P 3 L$ a good candidate for an $8 \mathrm{p}$ tumour suppressor gene. Like its homologue, $B N I P 3 L$ contains a sequence motif for a transmembrane domain and a putative proapoptotic BH3 (Bcl-2 homology-3) domain (Yasuda et al, 1999). BNIP3L interacts with the antiapoptotic viral proteins E1B19kD and BCL2 to induce cell death by altering mitochondrial membrane permeability (Chen et al, 1999; Imazu et al, 1999; Yasuda et al, 1999). Further evidence for a possible tumour suppressor role of the BNIP3L gene is provided by experiments showing that the clonicity in soft agar of cervical cancer cell lines was suppressed after transfection of the BNIP3L gene (Matsushima et al, 1998). Considering its function and location, BNIP3L is a strong candidate for the breast and/or ovarian cancer tumour suppressor gene located at $8 \mathrm{p} 21$.

In order to determine whether BNIP3L functions as a tumour suppressor gene in breast and/or ovarian cancer, we have analysed its expression in ovarian and breast cancer cell lines and screened all exons for mutations in a panel of primary ovarian and breast cancers.

\section{MATERIALS AND METHODS}

\section{Cell lines}

Human ovarian surface epithelial cell lines (HOSE) 1.1 and 17.1, immortalised with a retroviral vector expressing human 
papillomavirus oncogenes (Tsao et al, 1995), were cultured in RPMI 1640 with $10 \%$ FCS. The human ovarian cancer cell lines 27 27/87, A2780, CAOV3, CI8O135, COLO316, JAM, OAW 42, PEO1, PEO14, SKOV3 and OVCAR 3 were maintained in RPMI 1640 with $10 \%$ FCS, and HEY, DOV-13, OVCA 432, OVCAR-4, OVCAR-5 and OVCAR-8 were maintained in MEM alpha with $10 \%$ FCS. OVCA 420 was maintained in 1:1 MCDB105:M199 with 10\% FCS and $59 \mathrm{M}$ was maintained in DMEM with $10 \%$ FCS.

The human breast epithelial cell lines Bre-80-hTERT1 and Bre80-hTERT2 (gifts of $\mathrm{R}$ Reddel), immortalised with human telomerase cDNA, were cultured in 1:1 RPMI 1640:MCDB 170 with $10 \%$ FCS, and MCDB 170 with $10 \%$ FCS respectively. The human breast cancer cell lines BC 312, NB88, T-47D, ZR-75-1, BT20, MDA-MB-231, BT474 and BT483 were maintained in RPMI 1640 with $10 \%$ FCS with the latter two supplemented with $1 \mu \mathrm{g} \mathrm{ml}^{-1}$ insulin. The cell lines 21MT-1, 21MT-2 and 21NT were maintained in MEM alpha with 10\% FCS, $10 \mathrm{mM}$ HEPES, $1 \mu \mathrm{g} \mathrm{ml}^{-1}$ insulin, $2.8 \mu \mathrm{M}$ hydrocortisone and $0.1 \mathrm{~mm}$ nonessential amino acids. SK-BR-3 was maintained in DMEM with $10 \%$ FCS and MCF7 was maintained in MEM alpha with $10 \%$ FCS and $1 \mu \mathrm{g} \mathrm{ml}^{-1}$ insulin.

\section{Primary tumours}

Primary ovarian tumour cells were obtained from 40 patients with malignant ovarian neoplasms undergoing surgery (Table 2). There were 31 serous tumours, seven endometrioid tumours and two clear cell tumours. All patients were staged at laparotomy, in accordance with the recommendations of the International Federation of Gynaecology and Obstetrics (FIGO). Primary breast tumours were obtained from 25 patients with malignant tumours undergoing surgery (Table 3). All patients were staged at surgery, in accordance with the recommendations of the American Joint Committee on Cancer (AJCC) and Union Internationale Contre le Cancer (UICC). The corresponding constitutional DNA was available in all cases from peripheral blood. Informed consent was obtained from all patients.

\section{DNA and RNA isolation}

Cell lines were harvested for DNA and RNA extraction at about $80 \%$ confluence. Total RNA was extracted from breast and ovarian cell lines using the Tri-reagent (Sigma Castle Hill, New South Wales, Australia) following the manufacturer's instructions. PolyA+ RNA was prepared from total RNA using Dynabeads mRNA purification kit (Dynal, Carlton South, Victoria, Australia). For the primary ovarian tumours, tumour tissue was dissected free from necrotic and connective tissue and mechanically dispersed prior to collagenase treatment $\left(0.1 \mathrm{mg} \mathrm{ml}^{-1}\right.$ in Hanks balanced salt solution). Dead and red cells were then removed by Ficoll - Paque, and genomic DNA was extracted by the salting-out method (Miller et al, 1988). The purity of the resulting DNA is supported by the high frequency of $\mathrm{LOH}$ on chromosome 17 detected in ovarian tumour DNA prepared by this method (Leary et al, 1995). DNA was also extracted from peripheral blood and cell lines using the salting-out method. For breast tumours, DNA was extracted from snap-frozen pieces (containing at least $70 \%$ tumour cells) by proteinase $\mathrm{K}$ digestion, followed by phenol/chloroform extraction.

\section{Semiquantitative RT-PCR and Northern blot analysis}

cDNA synthesis was primed with random hexamers and carried out on $1 \mu \mathrm{g}$ of total RNA using Superscript II (Promega). Primers pairs were designed to span at least one intron to avoid contamination from genomic DNA. RT-PCR was performed using $1 \mu \mathrm{l} \mathrm{cDNA}$ incorporating ${ }^{33} \mathrm{P}$-dATP in a total volume of $20 \mu \mathrm{l}$. Reactions were multiplexed with primers for $\beta$-actin, which served as an internal control. All primer sequences are listed in Table 1. Products were taken out at the end of cycles 20, 25 and 30 in order
Table I Primers used in the analysis of the BNIP3L gene

\begin{tabular}{|c|c|c|c|}
\hline & & Sequence $\left(5^{\prime}-3^{\prime}\right)$ & Size (bp) \\
\hline \multicolumn{4}{|l|}{ RT-PCR } \\
\hline BNIP3L & $\begin{array}{l}F \\
R\end{array}$ & $\begin{array}{l}\text { ctgagtgccggagacggtcc } \\
\text { ctgccatcttcttgtggcgaagg }\end{array}$ & 364 \\
\hline$\beta$-actin & $\begin{array}{l}F \\
R\end{array}$ & $\begin{array}{l}\text { cgtgacaataaggagaagctgtgc } \\
\text { ctcaggaggagcaatgatcttgat }\end{array}$ & 375 \\
\hline \multicolumn{4}{|l|}{ Northern analysis } \\
\hline BNIP3L & $\begin{array}{l}\mathrm{F} \\
\mathrm{R}\end{array}$ & $\begin{array}{l}\text { ctgagtgccggagacggtcc } \\
\text { ctggcatttgcggaaaagaagccc }\end{array}$ & 993 \\
\hline GAPDH & $\begin{array}{l}\mathrm{F} \\
\mathrm{R}\end{array}$ & $\begin{array}{l}\text { atggatccagtccatgccatcactgcc } \\
\text { atggtaccgaggtccaccaccctgttg }\end{array}$ & 470 \\
\hline \multicolumn{4}{|c|}{ Homozygous deletion analysis } \\
\hline Exon I & $\begin{array}{l}\mathrm{F} \\
\mathrm{R}\end{array}$ & $\begin{array}{l}\text { ctgactcgagcgtctccacgtccg } \\
\text { cccatgcctgagccaatgagctgc }\end{array}$ & 444 \\
\hline Exon 2 & $\begin{array}{l}\mathrm{F} \\
\mathrm{R}\end{array}$ & $\begin{array}{l}\text { gacagatttcagttctgctgtgg } \\
\text { gtgaatgagccctgtaacccacctg }\end{array}$ & 295 \\
\hline Exon 3 & $\begin{array}{l}\mathrm{F} \\
\mathrm{R}\end{array}$ & $\begin{array}{l}\text { gcagaacattttgggagtaagaatgc } \\
\text { ccttagttgtaaaggagtgcg }\end{array}$ & 462 \\
\hline Exons 4 and 5 & $\begin{array}{l}F \\
R\end{array}$ & $\begin{array}{l}\text { gagacacaaccttatgagtttgg } \\
\text { caccacttcacaggtcacacgc }\end{array}$ & 640 \\
\hline Exon 6 & $\begin{array}{l}\mathrm{F} \\
\mathrm{R}\end{array}$ & $\begin{array}{l}\text { gcggtacccacaaacctttagagcc } \\
\text { caccacttcacaggtcacacgc }\end{array}$ & 221 \\
\hline \multicolumn{4}{|l|}{ DHPLC analysis } \\
\hline Exon I & $\begin{array}{l}\mathrm{F} \\
\mathrm{R}\end{array}$ & $\begin{array}{l}\text { ctgactcgagcgtctccacgtccg } \\
\text { cccatgcctgagccaatgagctgc }\end{array}$ & 444 \\
\hline Exon 2 & $\begin{array}{l}\mathrm{F} \\
\mathrm{R}\end{array}$ & $\begin{array}{l}\text { gacagatttcagttctgctgtgg } \\
\text { gtgaatgagccctgtaacccacctg }\end{array}$ & 295 \\
\hline Exon 3 & $\begin{array}{l}\mathrm{F} \\
\mathrm{R}\end{array}$ & $\begin{array}{l}\text { gcagaacattttgggagtaagaatgc } \\
\text { ccttagttgtaaaggagtgcg }\end{array}$ & 462 \\
\hline Exon 4 & $\begin{array}{l}\mathrm{F} \\
\mathrm{R}\end{array}$ & $\begin{array}{l}\text { gagacacaaccttatgagtttgg } \\
\text { gcgtgcgcagatcaactgtgtcc }\end{array}$ & 259 \\
\hline Exon 5 & $\begin{array}{l}\mathrm{F} \\
\mathrm{R}\end{array}$ & $\begin{array}{l}\text { cttgtcagtggacacagttgatctgc } \\
\text { gtagaacaattgtgcaccc }\end{array}$ & 414 \\
\hline Exon 6 & $\begin{array}{l}F \\
R\end{array}$ & $\begin{array}{l}\text { gcggtacccacaaacctttagagcc } \\
\text { caccacttcacaggtcacacgc }\end{array}$ & 221 \\
\hline
\end{tabular}

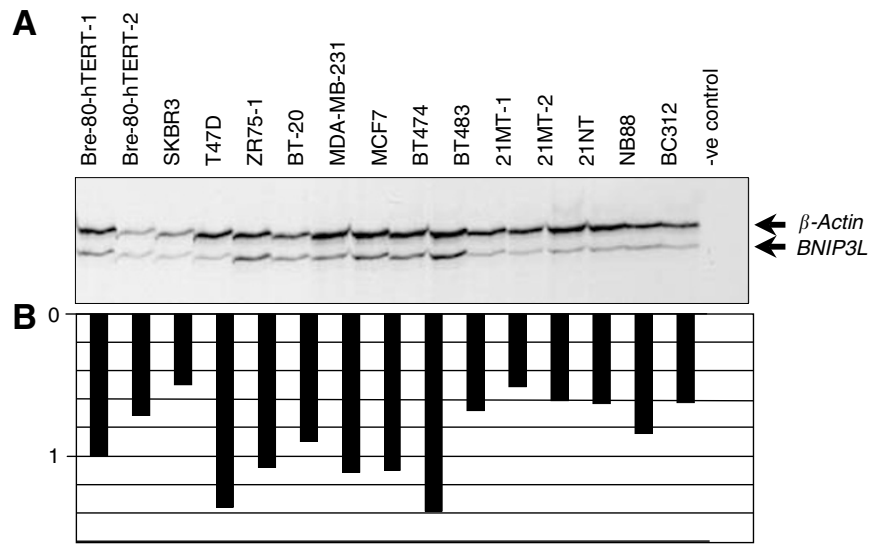

Figure I (A) Analysis of BNIP3L expression by RT-PCR in breast cancer cell lines. RT - PCR was carried out in a multiplex reaction with $\beta$ actin as an internal control for 20 cycles on cDNA from Bre-80-hTERT-I, Bre-80-hTERT-2 and 13 breast cancer cell lines. (B) Quantification of $B N I P 3 L$ expression relative to $\beta$-actin.

to assess amplification in the exponential phase, and these products were then run on a $5 \%$ denaturing acrylamide gel prior to autoradiography.

RNA was denatured and electrophoresed on a formaldehydeagarose gel and transferred to a nylon membrane (Amersham Hybond $\mathrm{N}+$ ) by capillary blotting overnight, then fixed to the membrane by ultraviolet irradiation according to standard protocols (Sambrook and Russell, 2001). Probe DNA was 
A
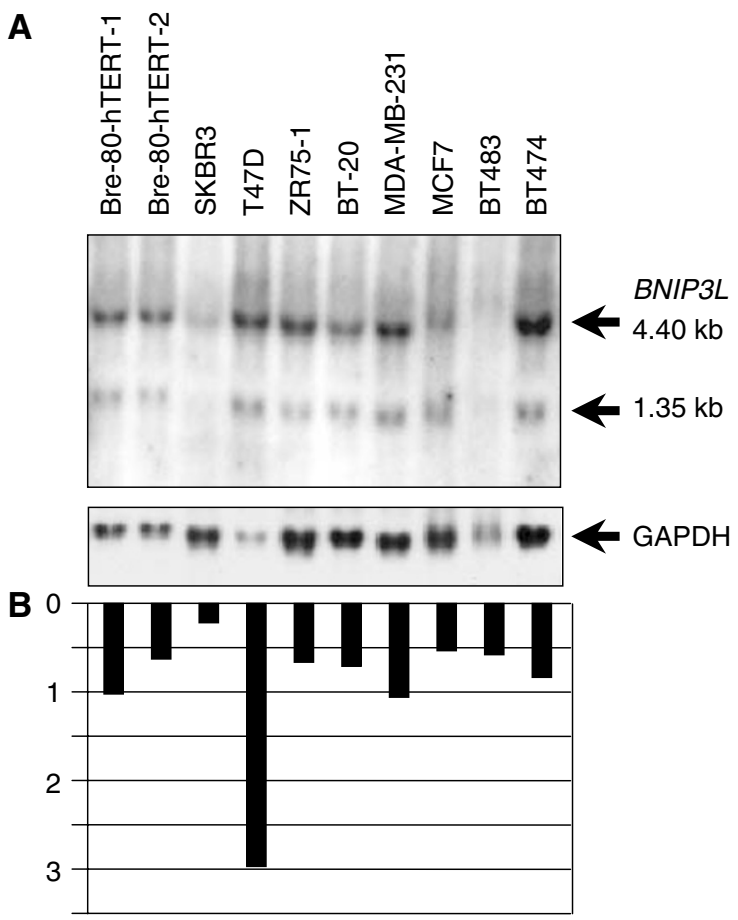

Figure 2 (A) Northern blot analysis of BNIP3L expression in breast cancer cell lines. Each lane represents $15 \mu \mathrm{g}$ of total RNA from Bre-80hTERT-I, Bre-80-hTERT-2 and 8 breast cancer cell lines. (B) Quantification of $B N I P 3 L$ expression relative to GAPDH.

A
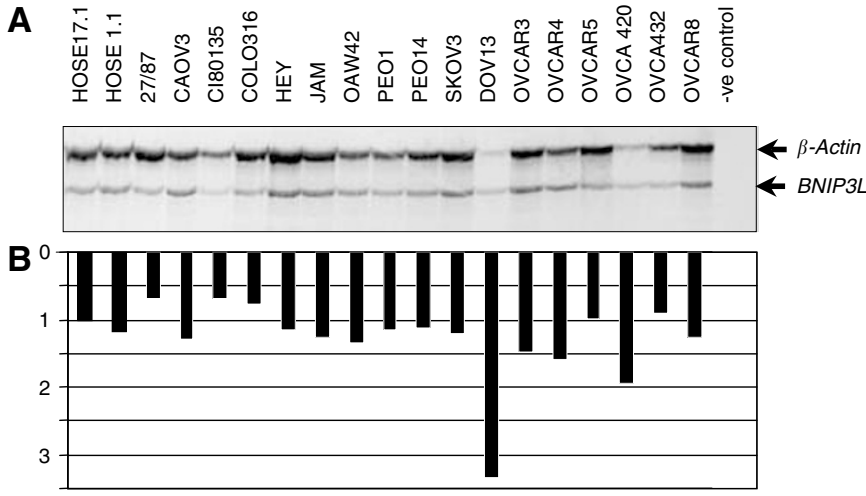

Figure 3 (A) Analysis of $B N I P 3 L$ expression by $R T-P C R$ in ovarian cancer cell lines. RT-PCR was carried out in a multiplex reaction with $\beta$ actin as an internal control for 20 cycles on CDNA from HOSE 17.I and HOSE I.I, and 16 ovarian cancer cell lines. (B) Quantification of BNIP3L expression relative to $\beta$-actin.

synthesised by RT-PCR (see Table 1 for primer details), and labelled with $\alpha^{32} \mathrm{P}$-dCTP by random priming (Amersham, Megaprime kit, Castle Hill, New South Wales, Australia) before being hybridised to the membrane for $2 \mathrm{~h}$ in ExpressHyb solution (Clontech Inc., Palo Alto, CA, USA) at $65^{\circ} \mathrm{C}$. The membranes were washed twice in $2 \times \mathrm{SSC} / 0.1 \% \mathrm{SDS}$ at room temperature, then twice in $0.1 \times \mathrm{SSC} / 0.1 \%$ SDS at $65^{\circ} \mathrm{C}$ before autoradiography. Membranes were then stripped with $0.5 \%$ SDS and reprobed with GAPDH that served as an internal control.

Autoradiographs of RT - PCR and Northern blots were scanned at $300 \mathrm{dpi}$ and the band intensity was determined by the ImageQuant program (Molecular Dynamics, Sunnyvale, CA, USA).

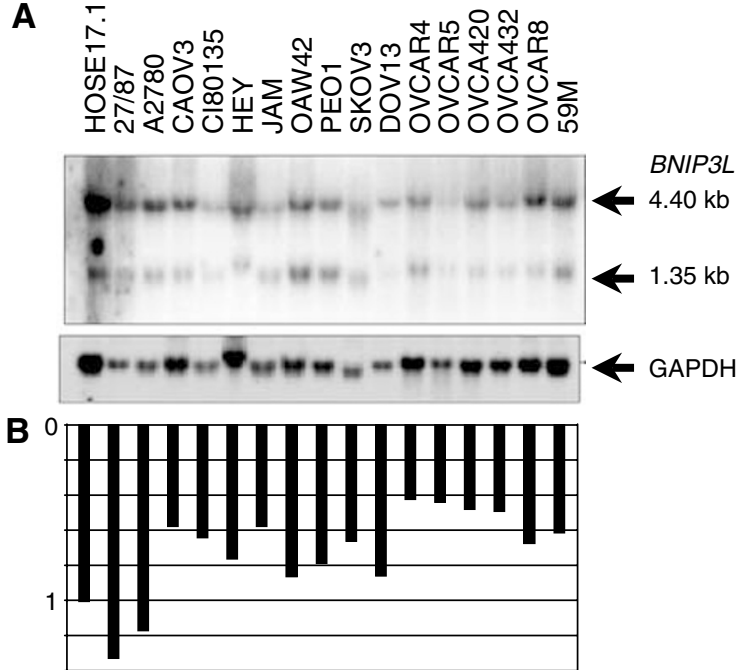

Figure 4 (A) Northern blot analysis of BNIP3L expression in ovarian cancer cell lines. Each lane represents I $5 \mu \mathrm{g}$ of total RNA from HOSE I7. and 16 ovarian cancer cell lines. (B) Quantification of BNIP3L expression relative to GAPDH.

Band intensity for $B N I P 3 L$ was expressed as a proportion of the $\beta$-actin or GAPDH value for RT-PCR and Northern analysis, respectively, with the value for the reference epithelial cells (HOSE 17.1 or Bre-80-hTERT1) set to 1.0.

\section{Homozygous deletion analysis}

Primers were designed to amplify the six exons of the BNIP3L gene (Table 1) and PCR performed on 20 ovarian and 15 breast cell lines. PCR products were visualised on an agarose gel. Samples were scored as deleted if a PCR failed when repeated with an internal control.

\section{LOH analysis}

Analysis was carried out with the D8S137 and D8S1048 microsatellite markers that are located 1.4 and $0.55 \mathrm{Mb}$ centromeric to the BNIP3L gene, respectively (http://www.celera.com). A measure of $5 \mathrm{ng}$ of DNA was amplified by PCR for 35 cycles incorporating ${ }^{33} \mathrm{P}$-dATP. PCR products were run on a $5 \%$ denaturing acrylamide gel and then visualised by autoradiography. $\mathrm{LOH}$ was scored by two independent examiners as a reduction in the intensity of one allele by at least $50 \%$. Any discrepancies between the two examiners were scored 'can't read' (CR).

\section{Denaturing high-performance liquid chromatography (DHPLC) analysis}

Primers were designed to amplify the coding regions of all exons of the BNIP3L gene (Table 1). PCR products were amplified from 10 to $100 \mathrm{ng}$ of genomic DNA using AmpliTaq Gold (PE Applied Biosystems) in a final volume of $20 \mu \mathrm{l}$. Amplicons were then denatured at $95^{\circ} \mathrm{C}$ for $5 \mathrm{~min}$ and cooled to $60^{\circ} \mathrm{C}$ over $30 \mathrm{~min}$ $\left(1^{\circ} \mathrm{C} \mathrm{min}^{-1}\right)$ prior to DHPLC. PCR products were loaded onto the autosampler and $5 \mu \mathrm{l}$ was injected onto the Varian Helix System (Varian, Walnut Creek, CA, USA). Samples were eluted within a linear acetonitrile gradient consisting of buffer A $(0.1 \mathrm{M}$ triethylammonium acetate and $0.1 \mathrm{mM}$ EDTA) and buffer B (0.1 M triethylammonium acetate, $0.1 \mathrm{~mm}$ EDTA and $25 \%$ acetonitrile) with a flow rate of $0.45 \mathrm{ml} \mathrm{min}^{-1}$. The buffer B gradient was $45 \%(0-0.5 \mathrm{~min})$, $50 \%(0.5-6 \mathrm{~min}), 68 \%(6-7 \mathrm{~min})$, and $45 \%(7-8 \mathrm{~min})$. 
Table $2 \mathrm{LOH}$ status, mutation results and clinicopathological features of primary ovarian tumours

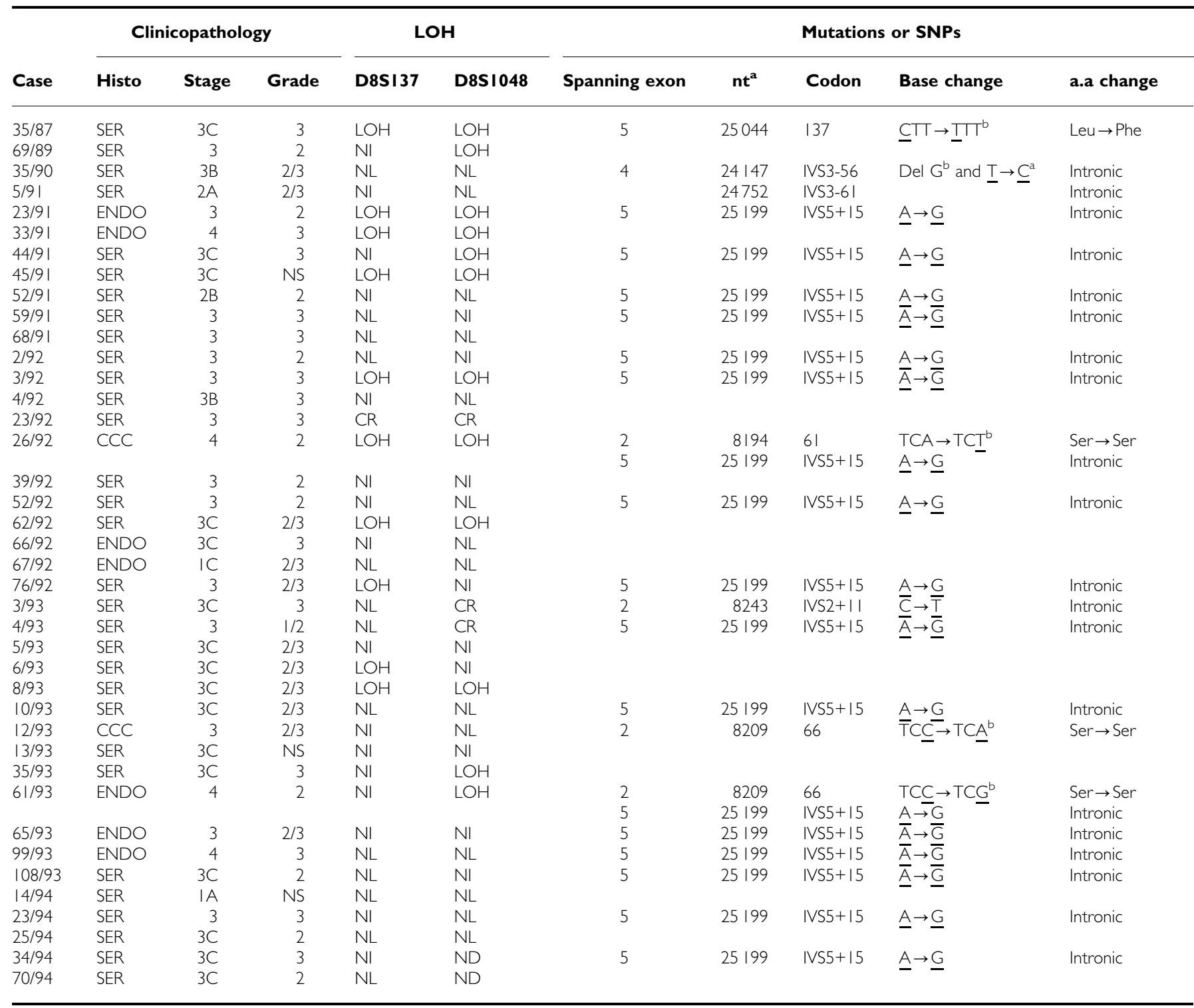

aBases counted from ATG start codon; NS=not specified; $N L=$ no loss; $L O H=$ loss of heterozygosity; $N I=$ not informative; $C R=$ can't read; $N D=$ not done.

DHPLC was carried out at both the recommended melt temperature as determined by the Stanford melt algorithm (http:// insertion.stanford.edu/melt.html) and 2 above the recommended temperature. The recommended melt temperatures are $65^{\circ} \mathrm{C}$ for exon $1,59^{\circ} \mathrm{C}$ for exon 2,53 and $58^{\circ} \mathrm{C}$ for exon 3,55 and $60^{\circ} \mathrm{C}$ for exon 4,54 and $59^{\circ} \mathrm{C}$ for exon 5 and $60^{\circ} \mathrm{C}$ for exon 6 . Analysis was performed using the Star Workstation version 5 (Varian, Walnut Creek, CA, USA). Samples that produced an aberrant shift in retention time and peak shape were repeated with their corresponding constitutional DNA to determine whether the shifts were tumour specific.

\section{Sequencing and cloning}

All PCR products producing shifts on DHPLC were reamplified and sequenced with both forward and reverse primers using ABI Prism Big Dye Terminator cycle Sequencing Ready reaction kit (PE Applied Biosystem) and analysed on an ABI 377 sequencer. In some cases, PCR products were also cloned into the pGEM-T vector (Promega) prior to sequencing with the M13 forward (-21) and reverse primers.

\section{RESULTS}

\section{Characterisation of $B N I P 3 L$ expression}

BNIP3L expression was analysed by both RT - PCR and Northern blot analysis in breast and ovarian cancer cell lines, as well as in cell lines derived from the corresponding normal epithelial cells. RT-PCR was performed on the immortalised human breast epithelial cell lines Bre-80-hTERT1 and Bre-80-hTERT2 and 13 breast cancer cell lines (Figure 1A). Expression was detected in both Bre-80-hTERT1 and Bre-80-hTERT2 and in all breast cancer cell lines at similar levels. Quantification of BNIP3L expression showed little variation in the 13 breast cancer cell lines when compared with two immortalised normal breast epithelial cell lines (Figure 1B). 
Table 3 LOH status, mutation results and clinicopathological features of primary breast tumours

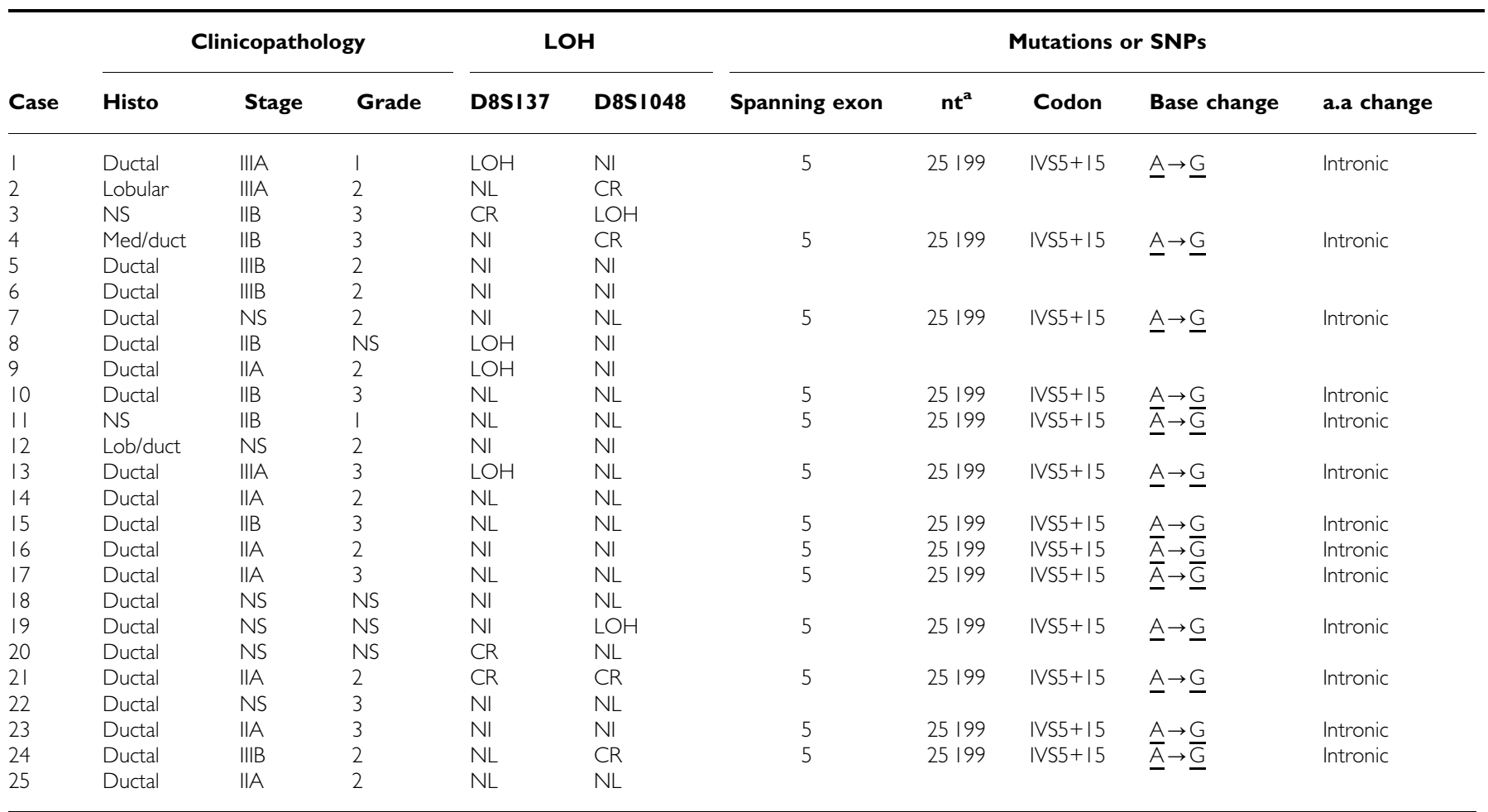

a Bases counted from ATG start codon; $N S=$ not specified; $N L=$ no loss; $L O H=$ loss of heterozygosity; $N I=$ not informative; $C R=$ can't read; $N D=$ not done.

BNIP3L expression was also examined by Northern blotting in a subset of eight of the breast cancer cell lines. Two transcripts of 1.3 and $4.4 \mathrm{~kb}$ were detected in the Bre-80-hTERT1 and Bre-80-hTERT2 cells and all breast cancer cell lines (Figure 2A). Apart from T47D, in which expression was increased, there was little variation in the level of expression in the remaining breast cancer cell lines compared to the Bre-80-hTERT cells, although there was some variability in the relative intensity of each transcript (Figure 2B).

For the ovarian cancer analysis, RT-PCR was conducted on HOSE 1.1 and HOSE 17.1, and 17 ovarian cancer cell lines (Figure 3A). Expression was detected in both HOSE cell lines and the 17 ovarian cancer cell lines. Of the 17 ovarian cancer cell lines, expression was notably different only in DOV-13, which showed about three-fold greater expression than the HOSE cell lines (Figure 3B).

$B N I P 3 L$ expression was also examined by Northern blot analysis in a subset of 16 ovarian cancer cell lines. As in the breast cell lines, two transcripts of 1.3 and $4.4 \mathrm{~kb}$ were detected in the HOSE 17.1 cell line and the 16 ovarian cancer cell lines (Figure 4A). BNIP3L was expressed by all the ovarian cancer cell lines, but the level of expression was reduced to approximately half that of HOSE 17.1 in six of the 16 cancer cell lines (Figure 4B). No aberrant transcripts were detected by Northern blot analysis.

\section{Analysis of genetic alterations at the BNIP3L locus}

No homozygous deletions within $B N I P 3 L$ were found in any cancer cell line (data not shown). $\mathrm{LOH}$ analysis was carried out on 40 primary ovarian tumours and 25 primary breast tumours, and their corresponding constitutional DNA to assess allelic loss at the BNIP3L locus. Two microsatellite markers were used, D8S137 and D8S1048. LOH was observed for at least one of the markers in 14 out of $34(41 \%)$ ovarian tumours. A frequency of $43 \%$ (10 out of 23 ) and $46 \%$ (12 out of 26 ) $\mathrm{LOH}$ was observed in informative ovarian tumours for D8S137 and D8S1048, respectively (Table 2). No correlation was found between $\mathrm{LOH}$ at either marker and tumour grade or histology. However, there was a statistically significant trend for $\mathrm{LOH}$ with later stage tumours $(P=0.03)$. A frequency of $33 \%$ (four out of 12) and $15 \% \mathrm{LOH}$ (two out of 13) was observed in informative breast tumours for D8S137 and D8S1048, respectively, with LOH observed for at least one marker in $28 \%$ (five out of 18) of the cases (Table 3). No correlation was found between $\mathrm{LOH}$ at either marker and tumour grade or stage.

\section{Mutation analysis}

Mutation analysis of BNIP3L was carried out on the same series of 40 primary ovarian tumours and 25 primary breast tumours by DHPLC. In the ovarian tumours, a total of five rare and one common polymorphisms were identified, as well as a single, intronic somatic mutation in case three out of 93. Direct sequencing of the PCR product from the three out of 93 tumour failed to show any change in nucleotide sequence, so the PCR product from both the tumour and constitutional DNA was cloned. A c.IVS $2+11 \mathrm{C}>\mathrm{T}$ conversion was detected in one out of four tumour clones and zero out of four constitutional DNA clones, suggesting that this mutation was somatic, which was consistent with the DHPLC chromatograph (Figure 5A). Four of the polymorphisms were detected in coding regions in cases $35 / 87$ (c.407C $>$ T, Figure 5B), 26/92 (c.181A $>$ T, Figure 5C), 12/93 (c.196C $>$ A) and 61/93 (c.196C $>$ G). These polymorphisms were all silent changes except for $\mathrm{c} .407 \mathrm{C}>\mathrm{T}$, which resulted in a change from leucine to phenylalanine. An intronic polymorphism involving a deletion and a substitution five bases apart was detected in case 35/90 (c.IVS3-56delG; c.IVS3-61T $>$ C). A second, common, intronic polymorphism (IVS5+15T $>C$ ) was detected in $16 / 38$ $(42 \%)$ cases. In the breast tumours, only the common IVS5+15T $>C$ polymorphism was detected in 13 out of 25 (52\%) of the cases. 

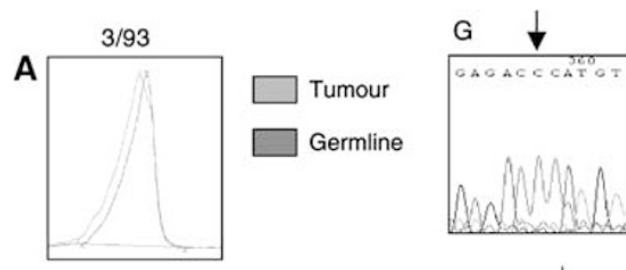

$35 / 87$
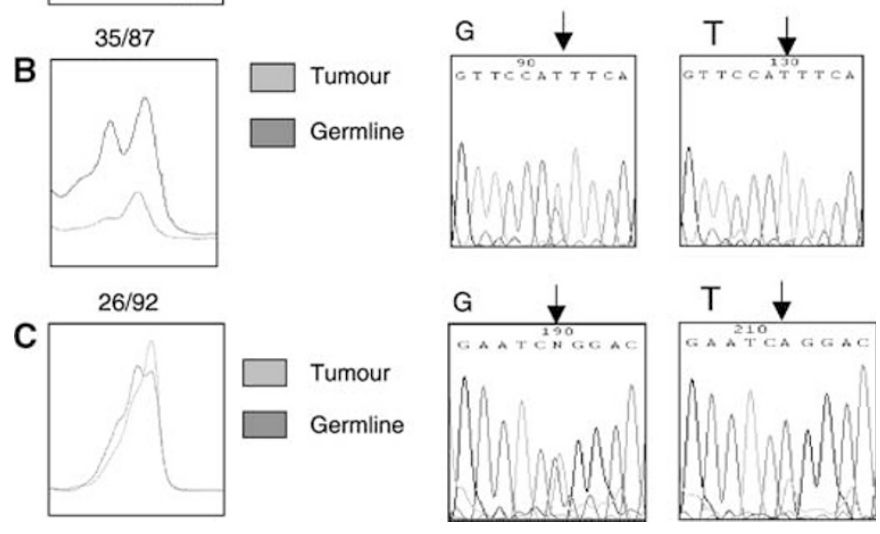

Figure 5 DHPLC shifts and sequencing results. (A) c.IVS2+IIC>T somatic mutation in case 3/93. $G=$ germline and $T=$ tumour DNA. (B) c.407C $>$ T polymorphism in case $35 / 87$ showing $\mathrm{LOH}$ of the $\mathrm{C}$ allele. (C) c. $181 \mathrm{~A}>\mathrm{T}$ polymorphism in case 26/92 showing $\mathrm{LOH}$ of the $\mathrm{T}$ allele.

\section{DISCUSSION}

$B N I P 3 L$ encodes a proapoptotic protein and is located at $8 \mathrm{p} 21$ (Matsushima et al, 1998; Chen et al, 1999; Imazu et al, 1999; Yasuda et al, 1999). BNIP3L reportedly induces cell death by altering mitochondrial membrane permeability and has been found to suppress clonicity in soft agar in cervical cancer cell lines (Matsushima et al, 1998). For these reasons, it is a good candidate for the $8 \mathrm{p} 21$ breast and ovarian cancer tumour suppressor gene.

RT - PCR and Northern blot analysis showed no evidence of frequent downregulation of BNIP3L expression in either breast or ovarian cancer cell lines. Northern blot analysis identified two transcripts of 1.3 and $4.4 \mathrm{~kb}$, which were similar in size to those reported by Yasuda et al (1999), who identified two transcripts of 1.6 and $3.9 \mathrm{~kb}$. Other investigators have only observed one transcript of either 1.45 (Matsushima et al, 1998) or $4.5 \mathrm{~kb}$ (Chen et al, 1998). Yasuda et al (1999) suggested that the two transcripts may be the result of alternative splicing or that one transcript may be derived from a closely related gene. We hypothesise that the larger transcript is an alternatively spliced form of the BNIP3L gene and hence quantitated BNIP3L expression as the sum of both transcripts.

Analysis of microsatellite markers near the BNIP3L locus detected frequencies of $\mathrm{LOH}$ of $43 \%$ (D8S137) and $46 \%$ (D8S1048) in the ovarian cancers. This is consistent with reported
LOH frequencies of $45-58 \%$ at 8 p21 in ovarian cancers (Lassus et al, 2001; Pribill et al, 2001). The frequency of $\mathrm{LOH}$ in the breast cancers of $27 \%$ (D8S137) and $28 \%$ overall is also consistent with a previous report of $30 \% \mathrm{LOH}$ at D8S137 (Seitz et al, 2000), but lower than the $49 \%$ reported at nearby marker D8S1116 (Yokota et al, 1999). In some cases ( 35 out of 87 and 26 out of 92), the LOH scored at the microsatellite markers was confirmed by the DHPLC analysis and sequencing.

The frequency of $\mathrm{LOH}$ was significantly higher in late-stage ovarian tumours suggesting that $\mathrm{LOH}$ at the D8S137 and D8S1048 loci occur in the progression rather than the initiation of ovarian cancer. A higher incidence of $\mathrm{LOH}$ in larger breast tumours $(50 \%$ $\mathrm{LOH}$ in tumours $>5 \mathrm{~cm}$ in diameter $v s 11 \%$ in tumours $<5 \mathrm{~cm}$ in diameter) observed in a previous report (Seitz et al, 2000) was not observed in our study.

Mutation analysis was carried out by DHPLC, resulting in the identification of one somatic mutation and six polymorphisms in the ovarian tumours and one polymorphism in the breast tumours. The single somatic mutation, in exon two, is a silent mutation in the flanking intron and therefore is unlikely to affect the protein function. The majority of the polymorphisms (four out of six) occurred in the coding sequence, and of these, three were silent changes in the third base of a codon. The fourth was a nonconservative substitution of phenylalanine for leucine at codon 137. This variant was present in the constitutional DNA, but underwent $\mathrm{LOH}$ in the tumour. The remaining two polymorphisms occurred in introns and were not located in any donor or acceptor consensus sequences, and so are unlikely to affect splicing.

There are five polymorphisms currently listed for BNIP $3 L$ in the Genbank database (XM_048074), one of which occurs in the $5^{\prime}$ UTR, one in the coding sequence (codon 48, c288G $>$ T), and three in the $3^{\prime}$ UTR. There are also two listed in the SNP consortium (http://snp.cshl.org/), one in the $5^{\prime}$ UTR and one in the first intron. Of these, only the polymorphism in the codon 48 could have been identified by our analysis and it was not detected in any of the cases analysed here.

The absence of mutations in BNIP3L in breast and ovarian tumours, and the lack of significant downregulation of the gene in either tumour type, suggests that $B N I P 3 L$ is not the target of $8 \mathrm{p}$ $\mathrm{LOH}$ in ovarian and breast tumours, despite its location in the SROs of LOH in ovarian cancer (Brown et al, 1999) and breast cancer (Yokota et al, 1999; Seitz et al, 2000). A number of other candidate tumour suppressor genes are also located within this region (STC1, ADAMDEC1, EXTL3, DOK2, DPYSL2, CLU and $N K X 3 A$ ), but further refinement of the region by $\mathrm{LOH}$ analysis of primary tumours or monochromosome-mediated chromosome transfer (MMCT) may be necessary before identification of the tumour suppressor is possible.

\section{ACKNOWLEDGEMENTS}

We gratefully acknowledge Karen Donn and Anna Marsh for their technical assistance with the DHPLC analysis.

\section{REFERENCES}

Bellamy CO (1997) p53 and apoptosis. Br Med Bull 53: $522-538$ Brown MR, Chuaqui R, Vocke CD, Berchuck A, Middleton LP, EmmertBuck MR, Kohn EC (1999) Allelic loss on chromosome arm 8p: analysis of sporadic epithelial ovarian tumors. Gynecol Oncol 74: $98-102$

Callahan R, Cropp CS, Merlo GR, Liscia DS, Cappa AP, Lidereau R (1992) Somatic mutations and human breast cancer. A status report. Cancer 69(6 Suppl): $1582-1588$
Chen G, Cizeau J, Vande Velde C, Park JH, Bozek G, Bolton J, Shi L, Dubik D, Greenberg A (1999) Nix and Nip3 form a subfamily of pro-apoptotic mitochondrial proteins. J Biol Chem 274: $7-10$

Claus EB, Schildkraut JM, Thompson WD, Risch NJ (1996) The genetic attributable risk of breast and ovarian cancer. Cancer 77: $2318-2324$

Imazu T, Shimizu S, Tagami S, Matsushima M, Nakamura Y, Miki T, Okuyama A, Tsujimoto Y (1999) Bcl-2/E1B $19 \mathrm{kDa}$-interacting protein 
3-like protein (Bnip3L) interacts with bcl-2/Bcl-xL and induces apoptosis by altering mitochondrial membrane permeability. Oncogene 18: $4523-4529$

Lassus H, Laitinen MP, Anttonen M, Heikinheimo M, Aaltonen LA, Ritvos O, Butzow (2001) Comparison of serous and mucinous ovarian carcinomas: distinct pattern of allelic loss at distal $8 \mathrm{p}$ and expression of transcription factor GATA-4. Lab Invest 81: 517-526

Leary JA, Kerr J, Chenevix-Trench G, Doris CP, Hurst T, Houghton CR, Friedlander ML (1995) Increased expression of the NME1 gene is associated with metastasis in epithelial ovarian cancer. Int J Cancer 64: $189-195$

Liu Y, Ganesan TS (2002) Tumour suppressor genes in sporadic epithelial ovarian cancer. Reproduction 123: 341 - 353

Matsushima M, Fujiwara T, Takahashi E, Minaguchi T, Eguchi Y, Tsujimoto Y, Suzumori K, Nakamura Y (1998) Isolation, mapping, and functional analysis of a novel human cDNA (BNIP3L) encoding a protein homologous to human NIP3. Genes Chromosomes Cancer 21: $230-235$

Miller SA, Dykes DD, Polesky HF (1988) A simple salting out procedure for extracting DNA from human nucleated cells. Nucleic Acids Res 16: 1215

Nihei N, Ichikawa T, Kawana Y, Kuramochi H, Kugoh H, Oshimura M, Hayata I, Shimazaki J, Ito H (1996) Mapping of metastasis suppressor gene(s) for rat prostate cancer on the short arm of human chromosome 8 by irradiated microcell-mediated chromosome transfer. Genes Chromosomes Cancer 17: $260-268$

Phelan CM, Borg A, Cuny M, Crichton DN, Baldersson T, Andersen TI, Caligo MA, Lidereau R, Lindblom A, Seitz S, Kelsell D, Hamann U, Rio P, Thorlacius S, Papp J, Olah E, Ponder B, Bignon YJ, Scherneck S, Barkardottir R, Borresen-Dale AL, Eyfjord J, Theillet C, Thompson AM, Devilee P, Larsson C (1998) Consortium study on 1280 breast carcinomas: allelic loss on chromosome 17 targets subregions associated with family history and clinical parameters. Cancer Res 58: 1004-1012

Pribill I, Speiser P, Leary J, Leodolter S, Hacker NF, Friedlander ML, Birnbaum D, Zeillinger R, Krainer M (2001) High frequency of allelic imbalance at regions of chromosome arm $8 \mathrm{p}$ in ovarian carcinoma. Cancer Genet Cytogenet 129: 23-29

Sambrook J, Russell DW (2001) Molecular Cloning: A Laboratory Manual, 3rd edn. New York: Cold Spring Harbour Laboratory Press

Seitz S, Werner S, Fischer J, Nothnagel A, Schlag PM, Scherneck S (2000) Refined deletion mapping in sporadic breast cancer at chromosomal region 8 p12-p21 and association with clinicopathological parameters. Eur J Cancer 36: 1507 - 1513

Shelling AN, Cooke IE, Ganesan TS (1995) The genetic analysis of ovarian cancer. Br J Cancer 72: 521 - 527

Tsao SW, Mok SC, Fey, EG Fletcher, JA Wan, TS Chew, EC Muto, MG Knapp, RC Berkowitz RS (1995) Characterization of human ovarian surface epithelial cells immortalized by human papilloma viral oncogenes (HPV-E6E7 ORFs). Exp Cell Res 218: 499-507

Wang JC, Radford DM, Holt MS, Helms C, Goate A, Brandt W, Parik M, Phillips N, DeSchryver K, Schuh ME, Fair KL, Ritter JH, Marshall P, Donis-Keller H (1999) Sequence-ready contig for the 1.4-cM ductal carcinoma in situ loss of heterozygosity region on chromosome 8p2223. Genomics 60: $1-11$

Welsch PL, King M-C (2001) BRCA1 and BRCA2 and the genetics of breast and ovarian cancer. Hum Mol Genet 10: 705-713

Wright K, Wilson PJ, Kerr J, Do K, Hurst T, Khoo SK, Ward B, ChenevixTrench G (1998) Frequent loss of heterozygosity and three critical regions on the short arm of chromosome 8 in ovarian adenocarcinomas. Oncogene 17: 1185 - 1188

Yasuda M, Han J, Dionne C, Boyd J, Chinnadurai G (1999) BNIP3 $\alpha$ : A human homolog of mitochondrial proapoptotic protein BNIP. Cancer Res 59: $533-537$

Yokota T, Yoshimoto M, Akiyama F, Sakamoto G, Kasumi F, Nakamura Y, Emi M. (1999) Localisation of a tumor suppressor gene associated with the progression of human breast carcinoma within a 1-cM Interval of 8p22-p23.1. Cancer 85: $447-452$

Zornig M, Hueber A, Baum W, Evan G. (2001) Apoptosis regulators and their role in tumorigenesis. Biochim Biophys Acta 1551: F1-37 